International Journal of Application Computer Science and Informatic Engineering (ACSIE)

Vol.1, No.1, May 2019, pp. 43 52

ISSN (print): $\mathrm{xxxx}-\mathrm{xxxx}$, ISSN (online): $\mathrm{xxxx}-\mathrm{xxxx}$

DOI: https://doi.org/10.33173/acsie.38

\title{
Design of E-Commerce Gift Shop Case Study MR. Kuta Bali
}

\author{
Bakhril Ilmi*1 $^{1}$, Putu Sugiartawan ${ }^{2}$, Ketut Laksmi Maswari ${ }^{3}$ \\ ${ }^{1,2,3}$ Teknik Informatika, STMIK STIKOM Indonesia; Jl. Tukad Pakerisan 97 Denpasar, Bali, 0361 - \\ 256 995/0361 - 246875 , Indonesia \\ e-mail: *1 bakhrililmi.stiki@gmail.com $, \underline{{ }^{2} \mathrm{xxx} @ \mathrm{xxxx.xxx}}, \underline{{ }^{3} \mathrm{xxx} @ \mathrm{xxxx} . \mathrm{xxx}}$
}

\begin{abstract}
E-commerce is an alternative which promising enough applied to companies at this time, because of e-commerce provide facilities for both sides, which is between merchant and customer. Although which transactions are conducted of being in two different though the continent, any transaction not there should have been negotiation stage and one of with poor this is a company gift shop. All this in MR.KUTA BALI, the transaction was done by using konvesional namely where clients visit directly to that place to choose and purchase products gift shop. The purpose of research is of designing and constructing system gift shop e-commerce case studies MR.KUTA BALI. Data collection is done by interviews to assistant general manager of the company gift shop mr.kuta bali by mrs. Umi Nur Aini. System building design was conducted using modeling DFD and the ERD to contrive in terms of relationships between table necessary. E-commerce system gift shop this they use of PHP language and in testing stage system done by using the method blackbox testing. The result has been testing the system in accordance with needs functionality designed.
\end{abstract}

Keywords-E-Commerce Gift Sho

\section{INTRODUCTION}

See the development of information technology that is increasingly sophisticated at this time, there are many types and opportunities for tourism business so that business transactions are increasingly carried out indirectly, one of which is by using internet technology. The development of the internet is fast and has a significant influence in all aspects of the running of a company. The presence of the internet, although still a new industry in the growth phase, has strengthened the belief in the importance of the role of technology in achieving the company's financial goals through the modification and efficiency of business processes by utilizing ECommerce.

The existence of E-Commerce is a promising business alternative to be applied to today's companies, because E-Commerce provides many conveniences for both parties, both from the seller and from the buyer in making trade transactions. In the transaction, even though the parties are on two different continents though, each transaction does not require a meeting in the negotiation stage, one of which is the souvenir company.

Mr.Kuta Bali is a company that provides services for people from both domestic and overseas who are on vacation to Bali to get various kinds of souvenirs typical of Bali. At this time Mr.Kuta Bali still uses conventional systems, where customers must go to the company to choose and buy the desired souvenir products. The company's product sales marketing system is 
still using Facebook, so that the ineffective sales and marketing process causes less profit. Some of these methods are considered to be less than optimal and not considered by the public, while the construction of new branches in remote areas of the company Mr.Kuta Bali is not possible because of limited space and costs.

Seeing these conditions, it is necessary to do an E-Commerce application design which is able to provide product sales facilities online. Through the E-Commerce application, companies can increase their sales by providing fast and accurate information to customers. Supported by a product ordering information system with a shopping cart and payment transactions using iPaymu. iPaymu is a way of online payment or money transfer that serves to facilitate users in transactions using internet services. iPaymu uses 256 bit SSL encryption and has been verified by Thwate, so the level of data security in the process of payment or remittance can be more secure and guaranteed.

Based on the description of the background, the authors are interested in conducting research under the title "Design of E-Commerce Gift Shop Case Study of Mr.Kuta Bali". It is expected that the system can facilitate customers in the process of ordering and payment of a product online, making a wider media campaign, and facilitate the company in the process of reporting transaction data.

\section{METHODS}

At this stage an analysis of the needs of the E-Commerce-based souvenir sales system is carried out. Some of the things analyzed at this stage include the needs of hardware and software so that the system can work and function as expected.

Data that will be used in making the design and building of the E-Commerce Gift Shop Case Study of Mr.Kuta Bali, which is in the form of category and item data as information about the contents of souvenir products that will be sold. Such products are: various kinds of barong clothes, t-shirts, pants, accessories (bracelets, earrings, etc.), typical Balinese snacks, sandals, paintings, bags, Balinese dresses, pearls and more.

\subsection{E-Commerce}

According to Wahana Komputer [1], E-Commerce is one of the advantages of the internet, until finally in the present era it seems that no day has been missed without hearing or reading the word E-Commerce in various information media. There are several names for ECommerce, namely Internet Commerce or Ecom, which basically has the same name designation. These terms mean buying or selling electronically and this activity is carried out on the internet network. E-Commerce can also mean advertising, sales and the best services using a webshop 24 hours a day for all of its customers

\subsection{Entity Relationship Diagram (ERD)}

Entity Relationship Diagram is the main data modeling tool and will help organize data in a project into entities and determine relationships between entities [2]. The process allows analysts to produce a good database structure so that data can be stored and retrieved efficiently.

There are 3 (three) types of symbols used in ERD, namely:

1. Entity

An entity is something real or abstract where we will store data. There are 4 classes of entities, for example employees, payments, campus, and books. Examples of an entity are called agencies, for example Adi, Joko's payment, and so on.

2. Relationship

Relationships Are natural relationships that occur between one or more entities, for example the employee payment process. Cardinality determines the occurrence

ACSIE Vol. 1, No. 1, May 2019: $43-52$ 
of an entity for an event in a related entity. For example, students can take many subjects.

3. Attributes

Attributes are a common feature of all or most agencies in certain entities. Other attributes are properties, data elements, and fields. For example, the name, address, employee number, and salary are the attributes of the employee entity. An attribute or combination of attributes that identifies one and only one agency an entity called the primary key or identifier. For example, employee numbers are the main key for employees.

\subsection{Data Flow Diagram Context Level (Context Diagram)}

The next model answers a number of questions in making SOPs. Context diagram (CD) is a special case of DFD (part of dfd which functions to map environmental models), which is represented by a single circle representing the whole system [3]. Figure 2.1 below is an example of a book ordering CD system.

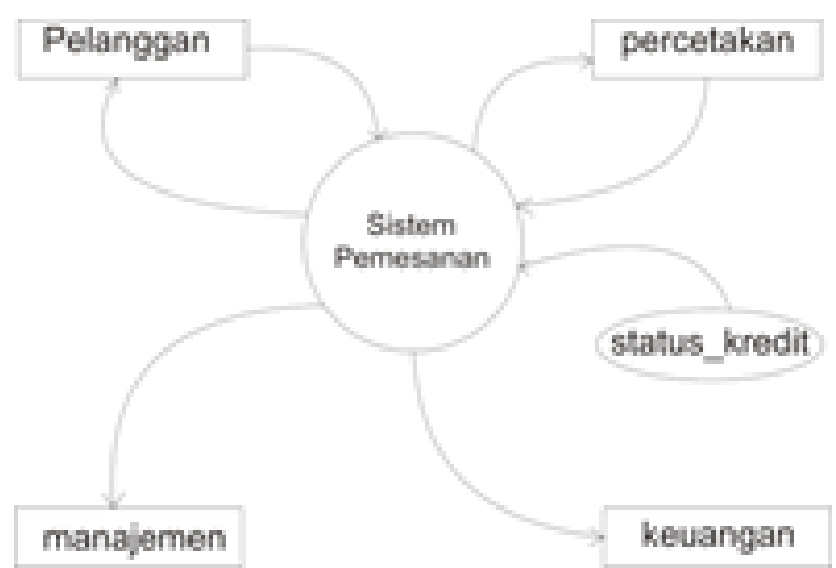

Figure 2.1 Context diagram of a book ordering system

\subsection{Data Flow Diagram (DFD)}

According to Saladin [4], Data Flow Diagrams (DFD) were originally developed by Chris Gane and Trish Sarson in 1979 which were included in the Structured Systems Analysis and Design Methodology (SSADM) written by Chris Gane and Trish Sarson. The system developed is based on the functional decomposition of a system. The following Figure 2.2 is an example of a DFD developed by Chris Gane and Trish Sarson:

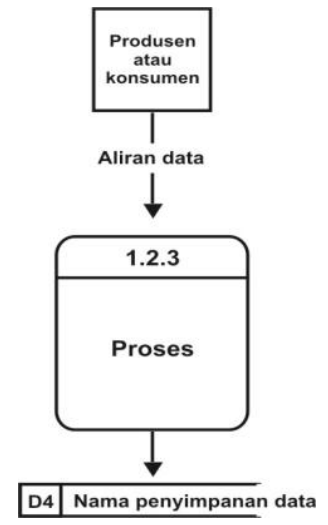

Figure 2. 2 Examples of DFDs developed by Chris Gane \& Trish Sarson 
Edward Yourdon and Tom DeMarco introduced another method in the 1980s which changed the square with curved angles (in DFD Chris Gane and Trish Sarson) with circles to denote. DFD Edward Yourdon and Tom DeMarco are popularly used as systems analysis models for software systems that will be implemented with structured programming.

The information contained in the software is modified with some needed transformations. Data Flow Diagram is a graphical representation that describes information flow and information transformation that is applied as data flowing from input and output.

DFD can be used to represent a system or software at several levels of abstraction. DFD can be divided into several levels that are more detailed to represent the flow of information or functions in more detail. DFD provides a mechanism for functional modeling or information flow modeling. Therefore, DFD is more suitable to be used to model software functions that will be implemented using structured programming because structured programming divides its parts with functions and procedures.

\subsection{PHP}

According to Ramadan [5], PHP is an acronym for Hypertext Preprocessor, which is a programming language based on codes (scripts) that are used to process data and send it back to the web browser into HTML code. The PHP code has special characteristics, namely:

1. Can only be run using a web server, for example: Apache.

2. PHP code is placed and run on the web server

3. PHP code can be used to access databases, such as: MySQL, PostgreSQL, Oracle, and others.

4. Is software that is open source.

5. Free to download and use.

6. It has multipaltform properties, meaning it can be run using any operating system, such as: Linux, Unix, Windows, and others.

Some ways to use PHP, besides providing benefits as in the above points, are also supported by many communities. This is what makes PHP continue to grow. We can learn more about tips and tricks for using it from various communities, educational institutions, or through internet media. Before learning PHP, you should do some preparations first, such as providing a web server and PHP editor help program. With a special editor, you can easily detect if a command write error occurs.

\subsection{Flowchart Sistem}

Flowchart system when the customer buys the product, the first step is that the customer will see the web display with related product information. After that, the customer makes a signup to register as a buyer if he doesn't have an account. If the account is already owned, the customer can sign in / login and the system will display the product with the buy button with the status enabled. Then the customer can choose and buy products by entering the purchase quantity. Data of selected products will be entered into cart / shopping cart to manage product data such as edit and delete products if the customer does not buy.

Products that have been fixed to be purchased can then be ordered by the customer, where the tax and transfer fees have been determined by the company. When entering the payment form, the customer will see the payment details for all products purchased, if the customer wants to continue payment, the customer must first login to your ipay account. Conversely, if it doesn't continue, then the customer will return to the product shop page as when after making a personal account login. After your ipay account login is successful, the customer can immediately confirm payment and the system will display a successful transaction page on the website page. The following is an overview of the E-Commerce gift shop system flowchart at Mr.Kuta Bali, shown in Figure 2.3.

ACSIE Vol. 1, No. 1, May 2019: $43-52$ 


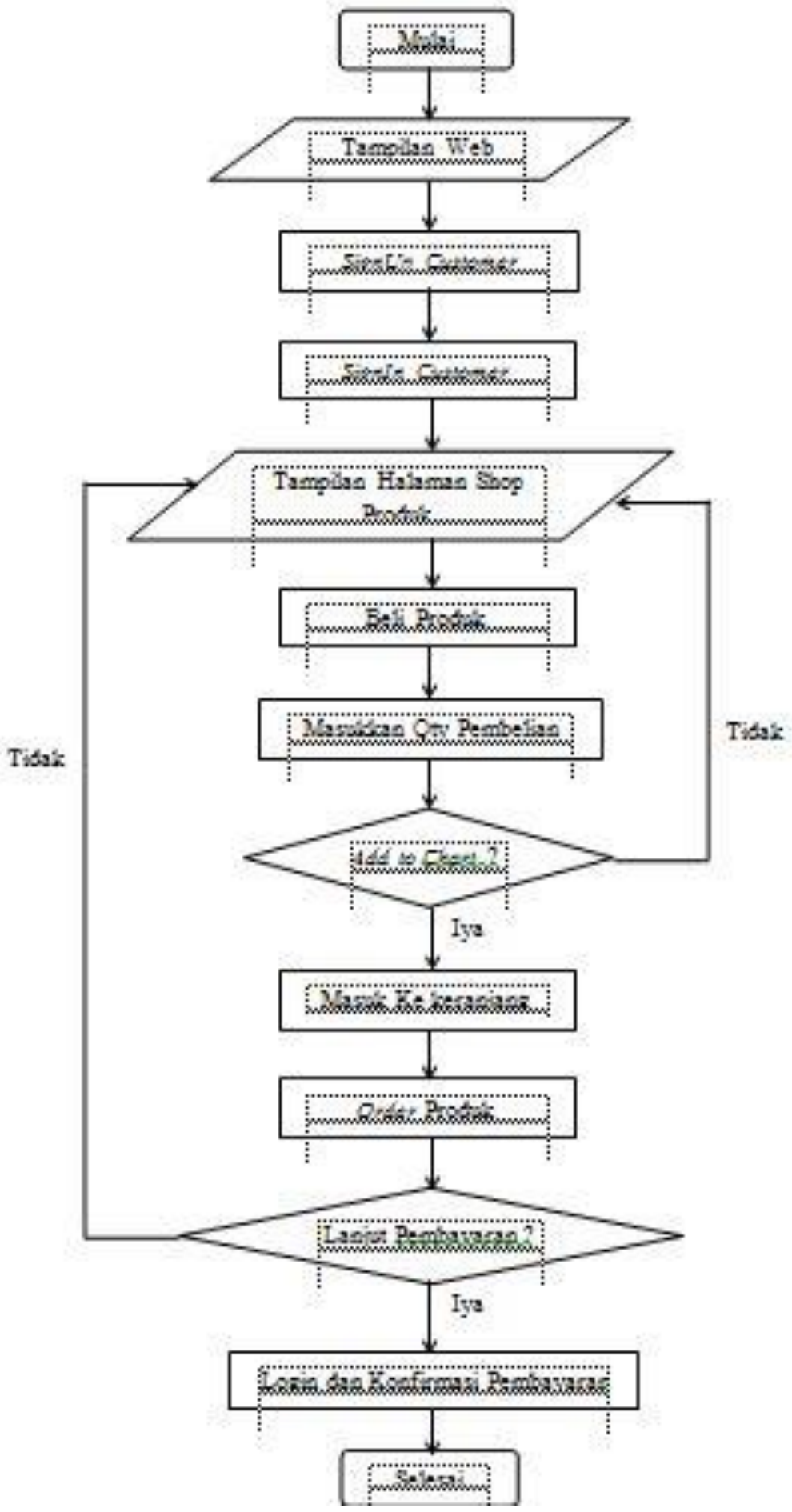

Figure 2.3 Flowchart of the E-Commerce Gift Shop System Mr.Kuta Bali

\subsection{Context Diagram dan DFD Level 0}

Here is the Context Diagram of the Mr.Kuta Bali E-Commerce Gift Shop System, shown in Figure 2.4 and continued to level 0 DFD (Figure 2.5). 


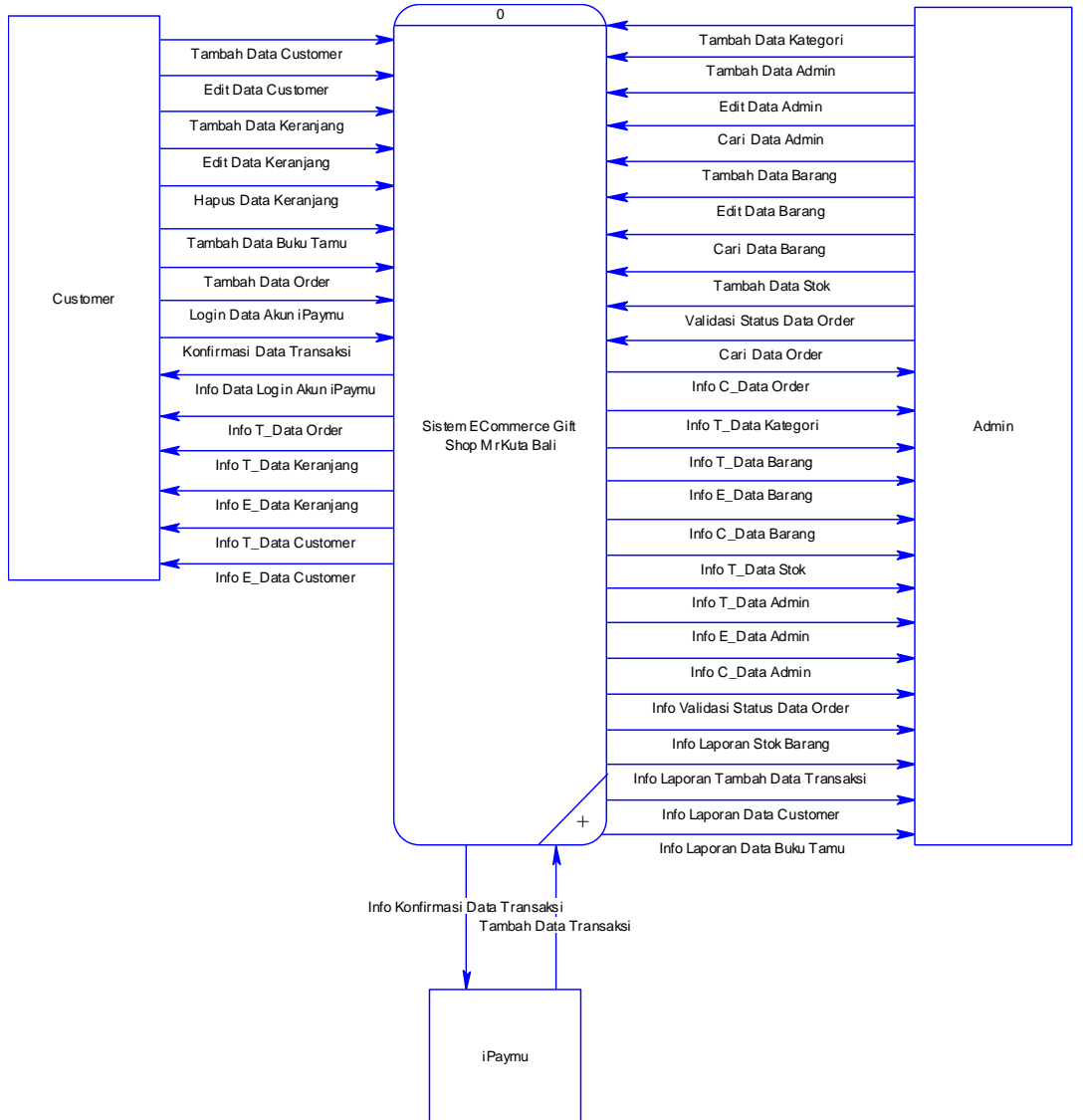

Figure 2.4 Context Diagram of the E-Commerce Gift Shop System Mr.Kuta Bali

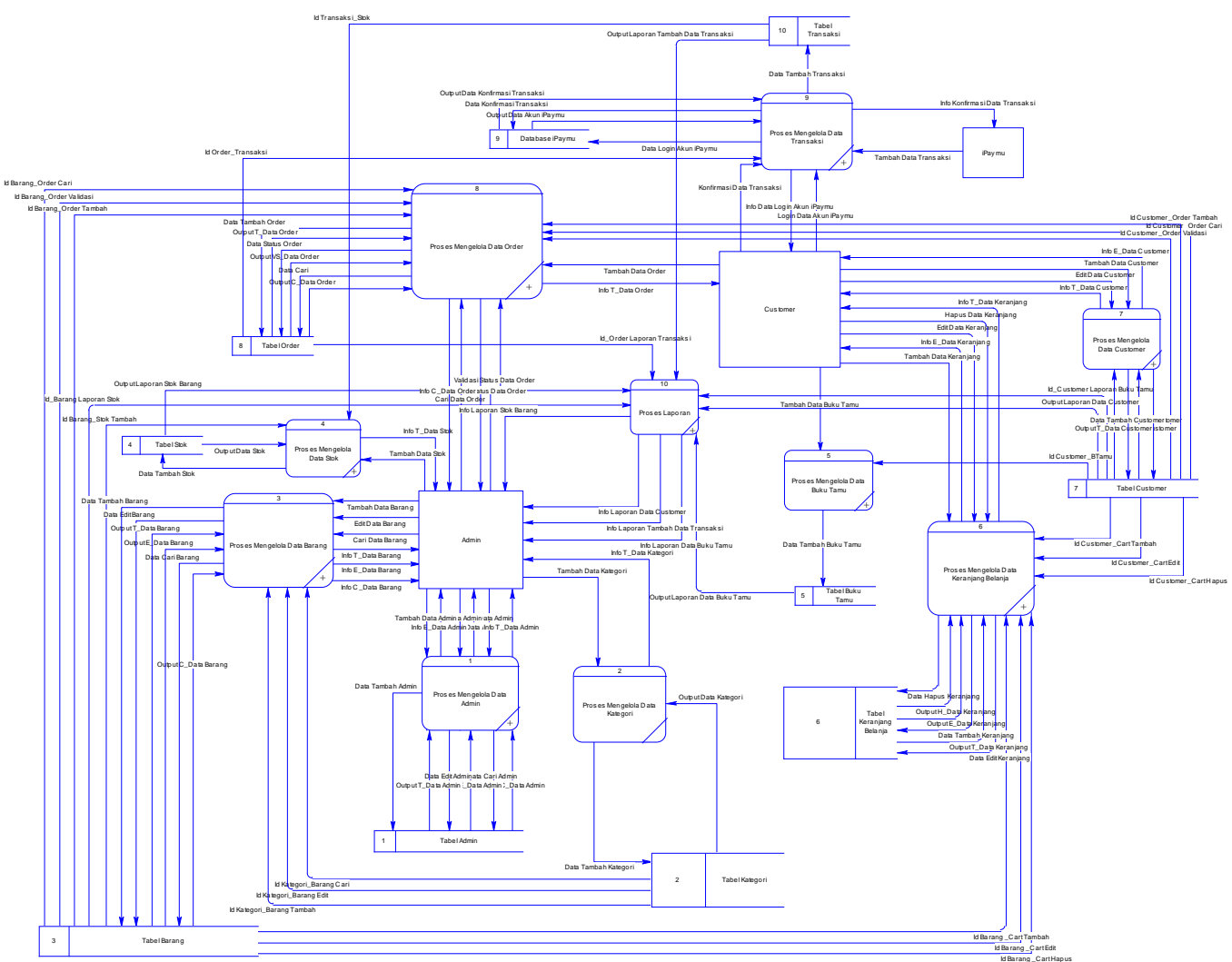

Figure 2.5 DFD Level 0 E-Commerce Gift Shop System Mr.Kuta Bali

ACSIE Vol. 1, No. 1, May 2019: $43-52$ 


\subsection{Entity Relationship Diagram (ERD)}

There are eight interconnected entities and each entity has its own attributes. The entity is an entity category, goods, admin, customer, guest book, order and transaction. Initially, the transaction entity has a relation to the order entity, where each transaction data has at least one order data and a maximum of one order data. Furthermore, the order entity that relates to two entities, namely customers and goods, where each order data can be ordered by at least one customer and a maximum of one customer, and has at least one item and a maximum of many items. The goods entity has a relationship with the admin and category, while the customer relates to the guest book.

Each admin can enter at least one and a maximum of many items, and each category has at least one item and a maximum of many items. Enter the last relation, that is, where each customer can fill at least one guest book and a maximum of many. Next is the Entity Relations Diagram of the E-Commerce Gift Shop Mr.Kuta Bali, shown in Figure 2.6.

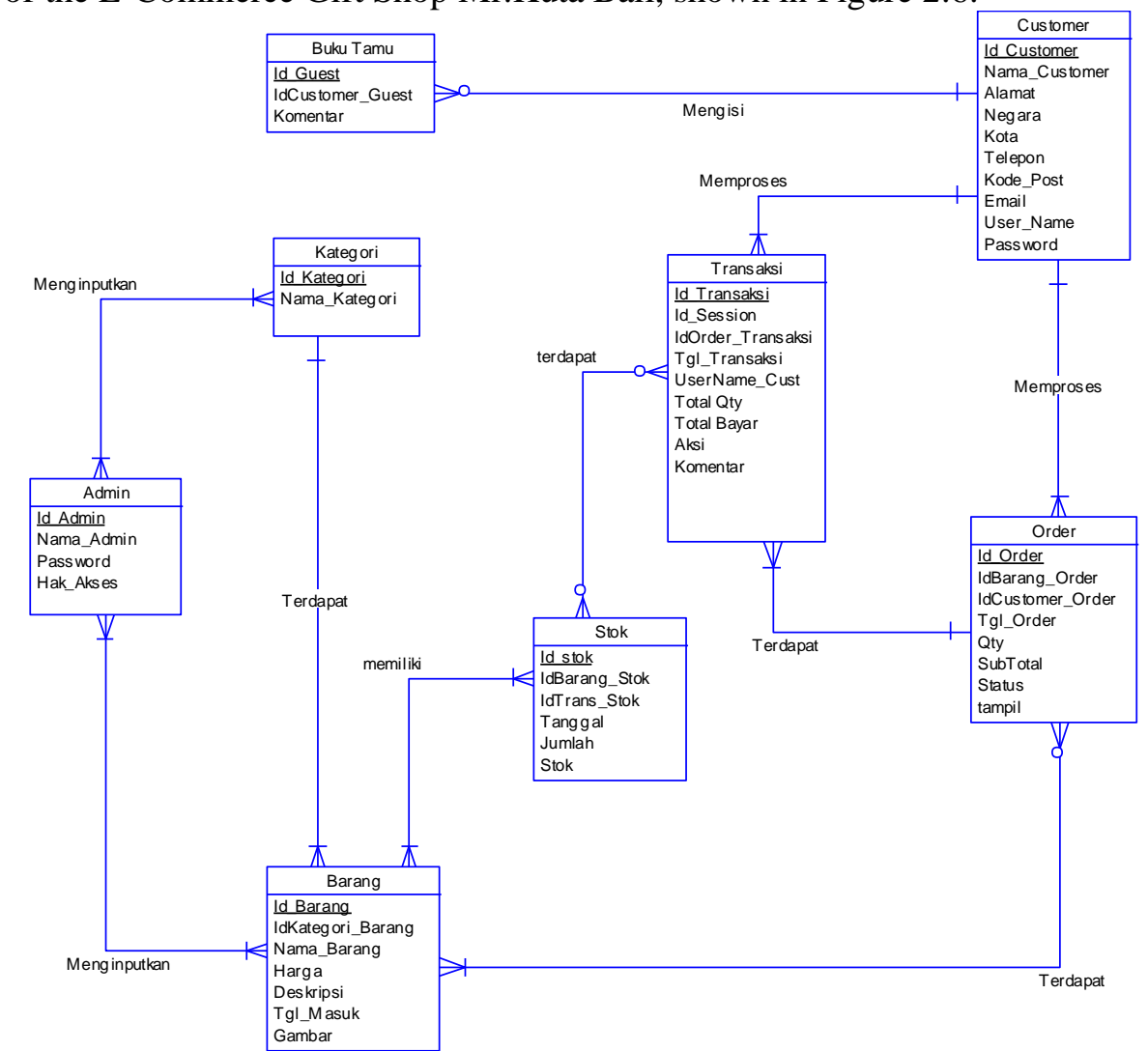

Figure 2.6 Entity Relation Diagram of the E-Commerce Gift Shop Mr.Kuta Bali

\section{RESULTS AND DISCUSSION}

The design implementation of this website is an implementation of website analysis and design in the previous chapter. It is expected that with this implementation it can be understood the way a website design E-Commerce is made, where the website will display various types of souvenir products along with prices related to the product.

Beginning to make a purchase, the customer must log in first by entering the username id and password previously created on the signup form. Customers can choose the desired product, then see the payment details on the product ordered. Payment is made by using iPaymu, where iPaymu is an online payment system that is used to facilitate online transactions.

3.1 Page Shop 
Here are the results of the shop page display. The corresponding display results are shown in Figure 3.1, the shop menu page, there are information on what products are sold. According to this information, the data displayed in the form of images, names, and prices of products where the data can change according to the wishes of the admin in processing the product. If the customer has successfully logged in the account and wants to purchase the product, the buy button will be status enabled to proceed to the add to cart page process.

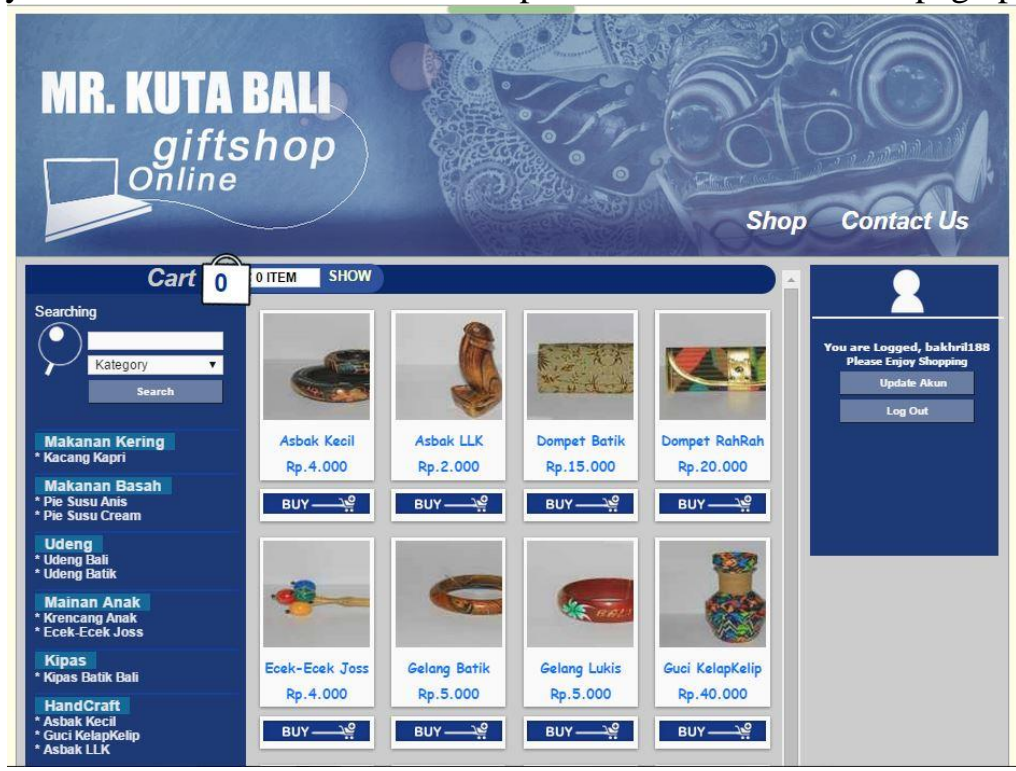

Figure 3.1 Shop page

\subsection{Halaman Add To Cart}

The following are the results of the add to cart display. The corresponding display results are shown in Figure 3.2, based on the add to cart page, there is more specific product information. The data displayed is in the form of categories, product names, prices, remaining stocks, descriptions and customers can enter the quantity of goods ordered in quantity. The amount ordered by the customer cannot exceed the capacity of the remaining stock, because the system will display a failed message if the customer does so. Products ordered will be accommodated on the cart page, where customers will be able to process the product data ordered by providing edit and delete services. Based on the product you want to order, there is also information on the related product categories.

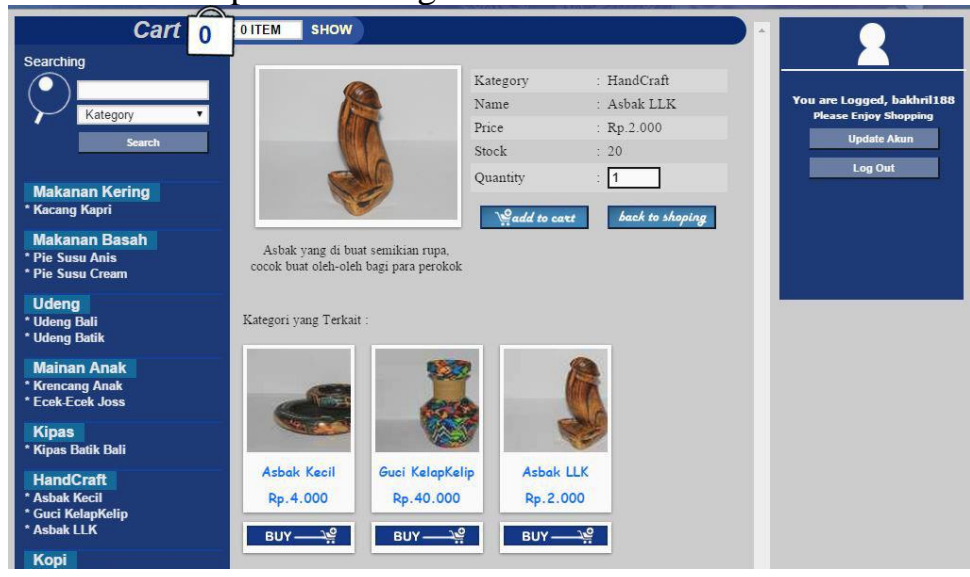

Figure 3.2 Page Add To Cart

ACSIE Vol. 1, No. 1, May 2019: $43-52$ 


\subsection{Admin Main Page}

The following are the results of the admin main page. The corresponding display results are shown in Figure 3.3, the following are the main pages of the admin, where there are several parts, namely the company logo, login data information, time information, navigation menu, content (Sign content), and the Sign Out button that functions to leave the rights admin access. The navigation menu has 4 menus, namely the item menu, validation, reports, and utilities. The item menu contains processed goods data such as adding, editing, and searching for goods or products. The next menu is the validation menu, which contains information on customer order data, where the order data will be changed when the customer has made a successful payment transaction and does not occur pending. Next on the report menu, where there are four submenus including the item inventory report, transaction reports, customer data reports, and guest book reports. The four reports are generated from the process of purchasing products between customers and the company web shop Mr.Kuta Bali.

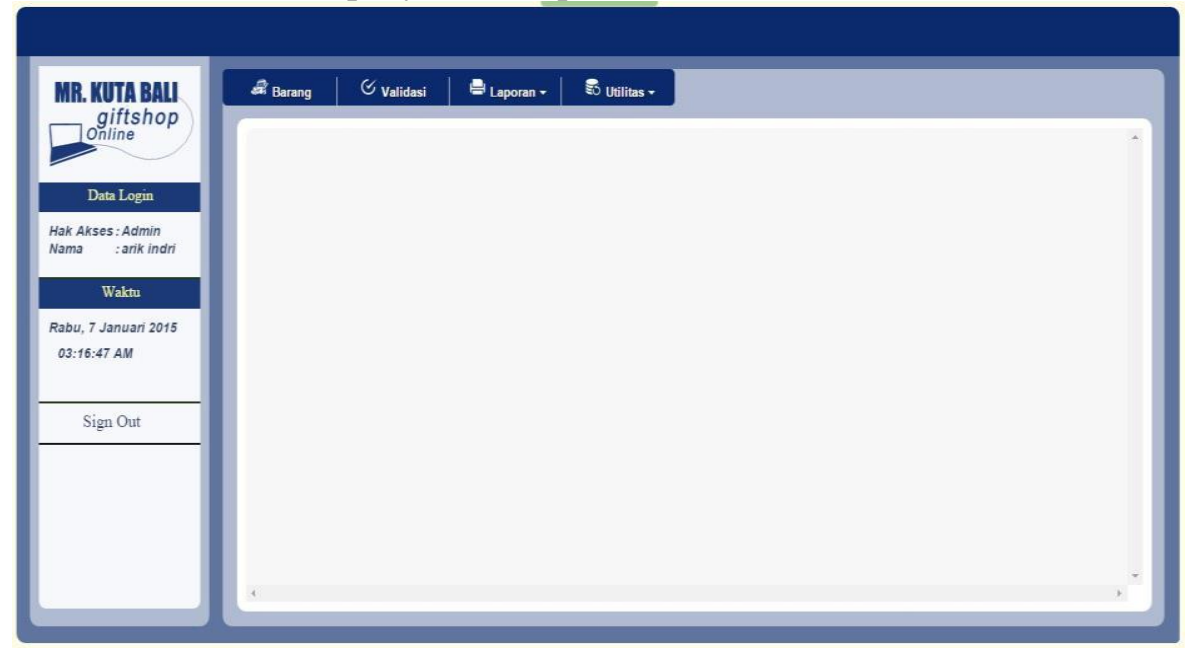

Figure 3.3 Admin Main Page Results

\section{CONCLUSION}

Based on the results of the research activities, the analysis of the website design system until the implementation stage, it can be concluded that the website of the E-Commerce Gift Shop Mr.Kuta Bali has been successfully built and can help the company to increase broader marketing online due to limited distance and time. Through marketing, customers can order products based on existing categories, and can directly make payments using iPaymu. IPaymu payment uses rupiah format status, so it can make it easier for customers to make transactions to the company. All subsequent transaction results will be processed into the admin page, which helps the admin in validating transaction data from customer product orders. Several processes are carried out until the transaction takes place, before the testing phase is carried out by using the blackbox testing method, where the tests performed get results that are in accordance with what is expected and valid.

\section{SUGGESTION}

The website of the E-Commerce gift shop Mr.Kuta Bali that has been designed and built is still far from perfect, therefore it is hoped that there will be parties who want to design and build this website to be more perfect. The program that is currently designed does not yet have a special feature to service all types of payments, so it can be considered in the future in terms of security and payment because the website designed still only uses payment with iPaymu. 


\section{DAFTAR PUSTAKA}

[1] Wahana Komputer. (2006). Apa \& Bagaimana E-Commerce. Yogyakarta: Andi.

[2] Paryudi. (2006). Basis Data. Yogyakarta: Andi.

[3] Iskandar. (1997). Pengantar Perancangan sistem. Bandung: Erlangga.

[4] Shalahuddin. (2011). Rekayasa Perangkat Lunak. Bandung: modula.

[5] Agustina. (2010). Mendesain Web dinamis dan menarik. Semarang: Andi.

[6] Barnes, dkk. http://www.webqual.co.uk. Pengenalan Tentang Webqual., diakses pada tanggal 27 Juni 2013.

[7] http://www.ipaymu.com. Cara Daftar iPaymu., diakses pada tahun 2014 (ONLINE)

[8] Ramadhan. (2005). Pemrograman Web dengan PHP database MySql. Jakarta: Elex Media.

[9] Jogiyanto. (2005). Sistem Teknologi Informasi. Yogyakarta: Andi.

[10] Raharjo. (2011). Belajar Pemrograman Web. Bandung: Modula.

[11] Wahana Komputer. (2012). Membuat Web E-Commerce dengan Adobe Dreamweaver CS5.5. Yogyakarta: Andi.

[12] Waloeya. (2011). Photoshop.com - Editor Grafis Online. Yogyakarta: Andi. 